\title{
NEPOS' BIOGRAPHICAL METHOD IN THE LIVES OF FOREIGN GENERALS
}

Abstract: This article argues that the programmatic statements in Nepos' preface to the Lives of Foreign Generals and in some of the Lives themselves help establish that his biographies emphasize the virtues of his subjects and not their res gestae. References to unlearned readers, often taken as an indication of the general ignorance of Nepos' audience, are actually a method for constructing an ideal reader who will be sensitive to cultural differences between Greeks and Romans and will understand the differences between biography and history.

consideration of Nepos' biographical method requires that
we take ourselves in medias res and join a discussion that has 1 been going on for some time. The scholarly consensus about his intellect, style and diligence in research has generally cast Nepos as second rate, especially when compared with his learned friends Cicero and Atticus. Nicholas Horsfall's severe judgment represents something of a low point in the appreciation of Nepos' work and abilities, ${ }_{1}$ but there have also been scholars who have found value in his writing, despite the infelicities of his style and the limits of his "intellectual horizons." ${ }^{2}$ Joseph Geiger has argued that Nepos invented political biography, ${ }^{3}$ while others have explored what he had to say about Rome and Roman values at the end of the Republic. ${ }^{4}$

More recently, in a study that takes Nepos seriously as a biographer without being unduly sympathetic, Frances Titchener has reexamined Nepos' place in the biographical tradition with the aim of presenting "a reasoned picture of Nepos' purpose, method, and style." ${ }^{5} \mathrm{I}$ am most interested in the section of her article that responds directly to Horsfall and defends the intelligence of Nepos and his audience. In the course of her discussion, Titchener looks to the programmatic statement in the Preface to the Lives of Foreign Gen-

${ }^{1}$ Horsfall (1982).

2 Conte (1994) 223. Conte (1994) 221-4 gives a more constructive overview of Nepos' place in Republican literature than does Horsfall, avoiding judgment about Nepos as an individual while still frankly assessing his style and intellectual achievement. Horsfall (1989) is less severe, but as Moles (1992) notes, some of his judgments are still harsh. For an example of the crudeness of Nepos' moralizing in comparison with Plutarch's, see Duff (1999) 228-9.

${ }^{3}$ Geiger (1985). For criticism of Geiger's claim, see Moles (1989). For a reevaluation of Geiger's argument, see Tuplin (2000).

${ }^{4}$ Cf. Dionisotti (1988); Millar (1988).

${ }^{5}$ Titchener (2003), updating and expanding on the argument of McCarty (1974). THE CLASSICAL JOURNAL 105.2 (2009/10) 109-21 
erals, in which Nepos appears to express concern that his audience, unfamiliar with Greek literature and culture, will censure the foreign customs of his biographical subjects and will thereby fail to recognize their virtues. This statement has often been used to characterize Nepos' readers as ignorant. Titchener, however, reads it as rhetorical, arguing that it does not condemn Nepos' readers but prepares them to be tolerant of non-Roman cultural values. In this article, I take Titchener's interpretation as a starting point, but I extend her conclusion and suggest that the programmatic statement of the Preface is part of an even larger rhetorical thread that runs through the book on foreign generals and helps establish Nepos' biographical method. Nepos, I believe, was encouraging his readers to accept a central tenet of his political biography: that his Lives of historical figures recount anecdotes and res gestae not for their own sake but primarily to elucidate character.

Following Titchener's lead, I begin with the Preface to the book on foreign generals. Nepos introduced this book with both a dedication and a problem (Pref. 1-3):

Non dubito fore plerosque, Attice, qui hoc genus scripturae leue et non satis dignum summorum uirorum personis iudicent, cum relatum legent, quis musicam docuerit Epaminondam, aut in eius uirtutibus commemorari, saltasse eum commode scienterque tibiis cantasse. sed ii erunt fere, qui expertes litterarum Graecarum nihil rectum, nisi quod ipsorum moribus conueniat, putabunt. hi si didicerint non eadem omnibus esse honesta atque turpia, sed omnia maiorum institutis iudicari, non admirabuntur nos in Graiorum uirtutibus exponendis mores eorum secutos.

I do not doubt, Atticus, that there are many who will judge this type of writing trivial and insufficiently appropriate to the characters of the greatest men, when they read my account of who taught Epaminondas music, or when it is included among his virtues that he danced well and played the flute skillfully. But these people will in general be those who, being inexperienced in Greek literature, will think that nothing is correct that does not conform to their own customs. If these people will understand that the same actions are not dignified and shameful in everyone's eyes, but that everything is judged according to the customs of one's ancestors, then they will not be surprised that I have followed the customs of the Greeks as I set forth their virtues. ${ }^{6}$

This statement led Horsfall to characterize Nepos' readers as a "monoglot, middlebrow public." Horsfall also makes a case for the decline in knowledge of Greek literature at the end of the Republic, concluding that Nepos' own Greek was weak and that "clearly none

${ }^{6}$ For the Latin text of Nepos I rely on Marshall (1991). Translations are my own. 
is presupposed in his readers." ${ }^{7}$ Titchener responds with a more sympathetic reading:

These are rhetorical statements, meant to exhort the readers to suspend judgmental thinking and keep an open mind, and face a certain reality about Greece and the Greeks. It is hardly the time for an author to spring truly unknown "bizarre" customs on an audience, but rather the time to bring in tried-and-true, well-known examples of how Greeks are different from Romans. ${ }^{8}$

Titchener correctly points out that these statements do not simply express Nepos' frustration or anxiety about his audience. But I think that Nepos is doing even more than reminding his readers that Greeks were different from Romans or, as Titchener goes on to argue, indicating that he was sympathetic to but not necessarily endorsing their foreign customs. He is also setting up an antithesis between perceptive and imperceptive readers.

In the opening sentences of the Preface, in fact, Nepos assumes two sorts of readers: the "many" who are ignorant of Greek literature and customs, and by inference, those who are well-read and sophisticated enough to appreciate that virtue can be culturally relative. The dedicatee, Atticus, would obviously have been among the latter group and therefore would not have considered the subject matter lightweight. He and Nepos must share the same sophisticated outlook, and so both of them can comprehend the author's dilemma. Here Nepos is treading familiar ground, for he himself famously received a similar dedication from Catullus (1.1-7):

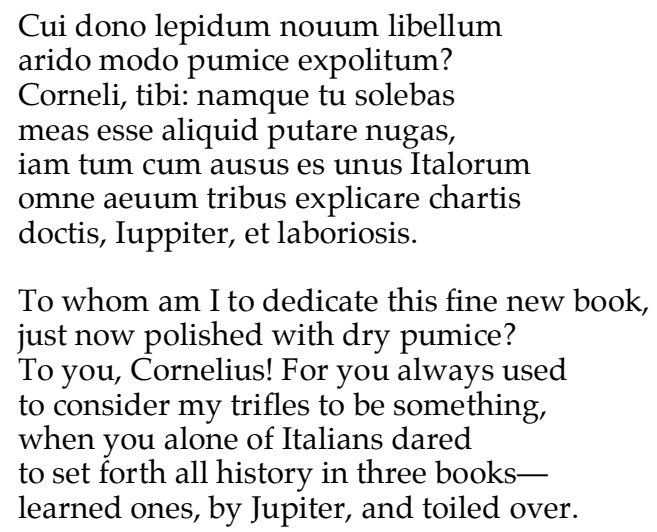

To whom am I to dedicate this fine new book, just now polished with dry pumice?

To you, Cornelius! For you always used to consider my trifles to be something, when you alone of Italians dared to set forth all history in three bookslearned ones, by Jupiter, and toiled over.

\footnotetext{
${ }^{7}$ Horsfall (1989) 113 and xix-xxi. Titchener (2003) 92 quotes more of Horsfall's criticism of both Nepos and his readers, and cites the similar conclusion of Rawson (1985) 49.

${ }^{8}$ Titchener (2003) 93.
} 
In Nepos as in Catullus, then, we meet a literary trope: the dedicatee wise enough to see past the superficial elements of a literary work and to appreciate its form or content on a deeper level. ${ }^{9}$

Returning to Nepos' Preface, we can see how he uses this trope to good rhetorical effect. As soon as he identifies the problem-some might consider the anecdotes in his book trivial-he consigns his potential detractors to a lower class, marking them as unlearned and so unable to grasp the significance of his writing. ${ }^{10}$ But Nepos, I believe, does not actually fear the criticism of the Greek-less reader. Rather, he is speaking protreptically, encouraging all his readers, whether knowledgeable about Greek customs or not, to join the more esteemed class of his dedicatee and to take a sophisticated look at the virtues of these generals, just as Catullus wants his readers to join Nepos and consider his own "trifles" significant. For a learned Roman could certainly have been dismissive of Greek culture, holding an ethnocentric bias when it came to judging character, and Nepos is hopeful that even the relatively unlearned might still grasp the idea that customs vary between cultures.

But even as he encourages his readers to keep an open mind about Greek customs in particular, Nepos introduces a technique that will help him to focus the readers' attention on his heroes' virtues in general. Here we may benefit from comparison with another ancient biographer. In discussing the relationship between narrator and narratee in Plutarch's Lives, Christopher Pelling identifies "cross-grained narratees" as readers who are not in agreement with the narrator's approach and are addressed by him differently from the more sympathetic readers. ${ }^{11}$ Nepos' potential detractors fall into the same category, not "entering into the spirit of the project," as Pelling says of Plutarch's narratees. There may have been a Greek-less public that Nepos felt compelled to address, but in fact these detractors need not have existed in order to serve their rhetorical purpose. ${ }^{12}$ Nepos, I suggest, has introduced cross-grained narratees

\footnotetext{
${ }^{9}$ I avoid the question of whether Catullus' dedication is to be taken at face value or as somehow critical of Nepos; see Tatum (1997) 485-8. I do believe that Catullus is sincere in his praise for Nepos' perception of the value in his own poetry, without necessarily committing to a compliment of Nepos' work; cf. Wiseman (1979) 171: "It has often been noticed that the virtues Catullus attributes to Nepos' work are just those which the sensitive and literate reader has been invited to see in his own libellus: innovation, conciseness, erudition and labor."

${ }^{10}$ Geiger (1985) 22 argues, rightly, in my opinion, that the phrase "genus scripturae leve" refers to the book on foreign generals and not to the genre of biography in general. For the opposite view, see Jenkinson (1967) and (1973).

${ }^{11}$ Pelling (2002b).

${ }^{12}$ Stadter (1988) 280 sees the problem posed in the Preface as artificial: "Since Atticus himself was a philhellene, and would hardly have been scandalized, e.g., by the philosophical interests of Epaminondas, and since in general the educated Roman of this period was quite cosmopolitan, the problem could not be a real one." Like Titch-
} 
mainly as a negative example for his actual readers to avoid. His immediate purpose in the Preface is to soften the readers' opinions about foreign customs. But Nepos returns to the theme of "the imperceptive observer" several times in the Lives of the generals, using it mainly to draw attention to his heroes' virtues and to justify passing over some of their great deeds. Far from merely betraying anxiety about the readers' "middlebrow" sensibilities, therefore, this passage from the Preface sets the stage for a broad rhetorical approach.

When we move from the Preface to the Lives themselves, we get a better sense of Nepos' method. One of his preoccupations is that his readers, left to their own instincts, could be disappointed by the content of the Lives. Even if they accept that a virtuous man might dance (in Greece, anyway), other unfulfilled expectations might impede their discernment of virtue. This is especially true when it comes to the narration of res gestae, which might be expected to dominate the biographies of military men. Nepos directly addresses the problem of selecting from historical material, but at the same time he continues to reinforce the idea that his readers must be perceptive and understand that virtue may not always be found in obvious places. In doing so, he applies the same rhetorical method as in the Preface. We read in the Agesilaus, for instance, of the problem posed by the Spartan's appearance (8.1):

Atque hic tantus uir ut naturam fautricem habuerat in tribuendis animi uirtutibus, sic maleficam nactus est in corpore fingendo: nam et statura fuit humili et corpore exiguo et claudus altero pede. quae res etiam nonnullam afferebat deformitatem, atque ignoti, faciem eius cum intuerentur, contemnebant; qui autem uirtutes nouerant, non poterant admirari satis.

But as for this great man, just as nature had favored him in granting virtues of the mind, so it had been malicious in forming his body: he was small in stature, feeble in body and lame in one foot. These factors produced a significant deformity, and those who did not know him, when they saw his outward appearance, dismissed him; but those who knew his virtues could not admire him enough.

The lesson is straightforward, and protreptic: Nepos has already advertised in the Preface that he intends to elucidate the virtues of his subjects, and our judgment of Agesilaus ought therefore to be made on that basis. Using Agesilaus' contemporaries as a model, Nepos again presents his readers with two classes of observers, and he subtly urges them to identify with the better, that is, the more perceptive class. The encouragement in this case is intimately connected to

ener (2003) 93-4, Stadter argues that Nepos is preparing his reader to be accepting of "exotic" customs. 
Nepos' project, since the experience of reading the Life provides Nepos' Roman audience with the same knowledge of Agesilaus' virtues that his Greek contemporaries could have had, allowing them to identify even more closely with the more perceptive observers presented in the text. In other words, everyone, Greek or Roman, has faced or now faces the same challenge: to "read" Agesilaus correctly in order to appreciate his character. ${ }^{13}$

Nepos encourages a similar introspective examination of Datames, the Carian general, in a passage at the end of the Timotheus $(4.5-6)$ :

Venio nunc ad fortissimum uirum maximique consilii omnium barbarorum, exceptis duobus Karthaginiensibus, Hamilcare et Hannibale. de quo hoc plura referemus, quod et obscuriora sunt eius gesta pleraque et ea, quae prospere ei cesserunt, non magnitudine copiarum, sed consilii, quo tum omnes superabat, acciderunt: quorum nisi ratio explicata fuerit, res apparere non poterunt.

I come now to the man who was bravest and best at strategy of all the barbarians, with the exception of the two Carthaginians, Hamilcar and Hannibal. About [Datames] I will give a fuller report because most of his accomplishments are quite ill-known and his successes were due not to the size of his army but to his capacity for strategy, in which he surpassed everyone of his time. Unless the reasoning behind them is explained, his accomplishments will not be able to be appreciated.

Nepos here is expecting more from his readers than a tolerance of strange Greek customs. He is asserting that even a quality considered good by both Romans and non-Romans, military success, must be appreciated in the proper manner. In this case, unless the ratio behind Datames' accomplishments is known, his res will not be understood. His res will not change; only the perception of them will be altered. Thus those who take only a superficial look at Datames' career might be impressed by his success on the battlefield, but they would fail to see the virtue behind it.

In the Epaminondas, Nepos is even more explicit about the danger of focusing only on accomplishments. After repeating his concerns about Greek customs from the Preface, he states that he wishes "to portray an image of the habits and life (imaginem consuetudinis atque uitae)" of his subject. Then he lists the topics related to his pur-

${ }^{13}$ Pelling (2002a) 257 describes a similar metatextual situation in Plutarch's Life of Caesar, where Caesar is reading about Alexander's accomplishments and weeps when he compares them to his own. That Life is the second half of the Alexander-Caesar pair, and so Plutarch, Pelling contends, may be alluding to "the inspiring power of reading about Alexander, just as his own readers have just read about Alexander in the paired Life, and just as Plutarch's Alexander looked forward to writings about himself (Alex. 14.9)." 
pose: Epaminondas' family, the subjects he studied in school and his teachers, his character and natural talents, anything else worthy of mention, and finally his res gestae, which, Nepos says pointedly and dismissively, "most people rank as more important than virtues" (Ep. 1.3-4). Once again, there are two classes of observers, and Nepos gently suggests that his readers join the more perceptive class, which treats virtue as paramount. Neither here nor in his comments on Datames does he treat res gestae as negligible, but he warns that in coming to terms with a man's life, they are not to be given priority over virtue. ${ }^{14}$

It is in the proper appreciation of virtues and deeds that Nepos has taken care to adopt a particular method for composing the biographies of great generals, where "great" may easily be taken to mean "glorious in war." Glory in war could be explained in several ways, and it was commonly attributed at least partly to the favor of fortune. ${ }^{15}$ Indeed, in the view of many in the ancient world, fortune played a role in all human endeavors and could bring about glorious victories for inferior generals, spectacular defeats for great generals, and anything in between. But a biographer is not interested in men who were only lucky or unlucky; his task is to find the virtues that lay behind a success or were overshadowed by an adverse fortune. Consider the problem posed by Nepos in the introduction to the Thrasybulus. He begins this Life by explaining how fortune played a role in hiding the greatness of this Athenian general $(1.1,1.3)$ :

Si per se uirtus sine fortuna ponderanda est, dubito an hunc primum omnium ponam. illud sine dubio: neminem huic praefero fide, constantia, magnitudine animi, in patriam amore.... sed nescio quo modo, cum eum nemo anteiret his uirtutibus, multi nobilitate praecucurrerunt.

If virtue is to be considered on its own merits, separate from fortune, I am unsure whether I would put [Thrasybulus] ahead of all men. But there is no doubt about this: I put no one before him in loyalty, steadfastness, greatness of mind, and love for his own country.... But somehow, although no one excelled him in these virtues, many surpassed him in honor.

Thrasybulus, as a historical figure, has a public relations problem: he was a more successful general than Alcibiades, Nepos tells us, but Alcibiades had a gift for getting full credit for all the accomplish-

${ }^{14}$ For a more detailed examination of the particular virtues of Epaminondas that interest Nepos, see the article that follows by Rex Stem.

${ }^{15}$ E.g. Sulla was called "lucky" (felix) and according to Plutarch even admitted to relying more on fortune than on virtue: "Moreover, judging by what [Sulla] says about being more naturally suited for Fortune than for war, he seems to have given more credit to Fortune than to his own virtue and to have devoted himself completely

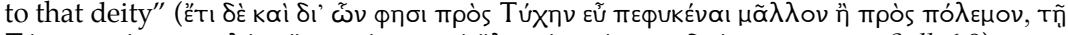

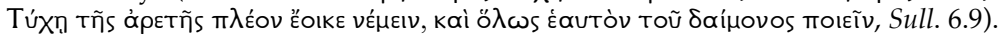


ments they shared. Thrasybulus' story presents a nice opening for a biographer interested in great men, since history has not created insurmountable assumptions in the reader's mind. But it also creates a dilemma. If Nepos were to bring the reader up to date, by recalling all the successes that belonged to Thrasybulus, his biography could end up looking more like history, and his subject's res gestae could dominate the narrative.

Nepos confronts this dilemma in the proem to the Life of Pelopidas, who he claims is a rather obscure figure, "better known to historians than to the man in the street," as he says. He goes on to confess that he is doubtful about how to proceed (1.1):

Cuius de uirtutibus dubito quem ad modum exponam, quod uereor, si res explicare incipiam, ne non uitam eius enarrare, sed historiam uidear scribere: si tantummodo summas attigero, ne rudibus Graecarum litterarum minus dilucide appareat, quantus fuerit ille uir. itaque utrique rei occurram, quantum potuero, et medebor cum satietati tum ignorantiae lectorum.

I am unsure how to present his virtutes, because I am afraid that if I begin to explain his res, I will appear not to be relating his vita but to be writing a historia; whereas if I only touch on his most significant accomplishments, it might be less clear to those unfamiliar with Greek literature how great a man he was. And so I will address both issues as best I can, and I will treat both the satiety and the ignorance of my readers.

This passage has often been taken to show that Nepos conceived of biography as a genre distinct from history, but also that he admitted that his readers were unlearned. The conclusion about his conception of the genres appears sound, ${ }^{16}$ and in fact it is not so separate from the characterization of his readers. If we interpret this characterization as part of Nepos' method, as with the examples above, we see that he uses these rudes Graecarum litterarum to set the proper expectation for his handling of res gestae. That is to say, he invokes them not for their own sake, but to alert all his readers that they will find here an exploration of Pelopidas' life but not an exhaustive narration of his deeds. ${ }^{17}$

Nepos' concern that his vita of Pelopidas might become a history compels us, as it has other students of Nepos, to compare a similar programmatic statement in Plutarch, who raised the same problem but for the opposite reason. The comparison yields further insight into the generic tension between history and biography and into the problem of detecting virtue amidst an abundance of res gestae. In the proem to his Lives of Alexander the Great and Julius Caesar, Plutarch

\footnotetext{
${ }^{16}$ Cf. Geiger (1985) 21-9; Momigliano (1993) 98-9.

${ }^{17}$ For the interconnectedness of Nepos' characterizations of Pelopidas and Epaminondas, see Manuwald (2003).
} 
deals with the challenge of writing about heroes who were too well known (Alex. 1.1-2):

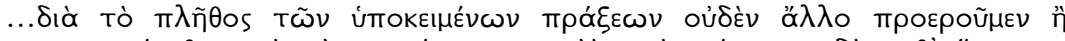

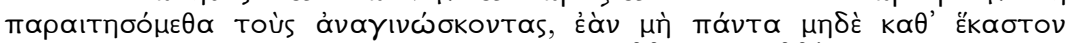

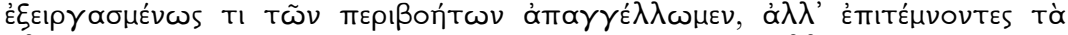

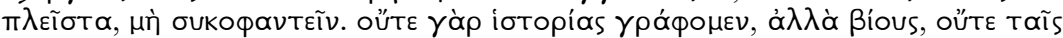

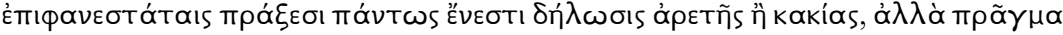

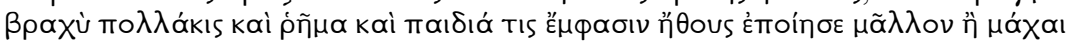

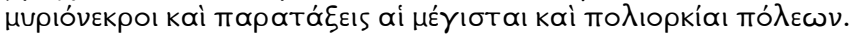

...Because a great number of accomplishments are available [for this book], by way of introduction I will only ask my readers not to quibble if I do not report all the famous deeds of these men or cover each one thoroughly, but instead abridge most of them. For I am not writing histories but lives, and the revelation of virtue or vice is not always contained in a man's greatest deeds, but often a slight thing, a saying or a jest, creates an impression of character, rather than battles with myriad casualties or great commands or the besieging of cities. ${ }^{18}$

This passage has often been taken as the key to Plutarch's biographical method, but lately scholars have been more cautious. Timothy Duff argues that Plutarch is facing a particular problem in this book-an abundance of well-known material-and advises against applying this statement to his entire corpus or to ancient biography in general. According to Duff, "it was generally assumed in antiquity that character could best be understood by examining men's actions" and "as a result, the analysis of character was most often conducted as part of a narrative of deeds." ${ }^{19}$ Plutarch, then, is preparing his reader for a different approach in this pair of Lives, making the case that his subjects' great deeds are not necessarily the best indicators of their character. Pelling builds on Duff's discussion and argues that although Plutarch elevates the importance of small deeds, he is not eschewing great ones. Pelling argues that Plutarch, in the proem to the Alexander-Caesar, is "introducing a polarity of 'small things' and 'big things' which prepares for a variety of interactions through the pair, and as we go on it may prove more difficult to keep small things and big things so separate." ${ }^{20}$ The point about Plutarch's approach in this book is important, because it sensitizes us to the close connection between a man's res gestae and the man himself. That is to say, even though Alexander and Caesar's legendary accomplishments may obscure our view of their character, those same accom-

${ }^{18}$ Titchener (2003) 87 discusses a related statement in Plutarch's Nicias, where Plutarch claims that he will not describe in detail the deeds of Nicias that Thucydides and Philistus have already written about in their histories (Nic. 1.6). For "quibble" as the translation for бUKофаvтєі̃ in this context, see Pelling (2002b) 276-7.

${ }^{19}$ Duff (1999) 15.

${ }^{20}$ Pelling (2006) 266. 
plishments are very likely the fruit of their character. Thus Plutarch is not announcing that he will ignore his heroes' great deeds, but is promising to narrate them only as necessary for illuminating ethos.

Nepos appears to have applied the same principle regularly in his Lives of the generals. He introduces res gestae into his biographies but warns his readers not to exaggerate their importance, and he often shapes his narrative to keep great battles and other similar events in the background. In the Miltiades, for instance, Nepos devotes three of eight chapters to the battle of Marathon. But the first two of those chapters describe preparations for the battle, while the third is devoted to the honors granted Miltiades afterward. The battle itself is reduced to a single sentence that underscores the character of the Athenians: "The Athenians had such a great advantage in virtus that they routed an enemy force ten times larger than their own, and they struck so much terror into the Persians that they fled not to their camp but to their ships" (5.5). ${ }^{21}$ The battle of Marathon is central to the res gestae of Miltiades and occupies a similar importance in his vita, but Nepos emphasizes the personal virtue of the soldiers, and that only briefly, rather than their deeds.

We may view this selection of material as one of the primary challenges that faced Nepos when he wrote biographies of military men. His response to this challenge, which he rhetorically cast as a dilemma, was to find a balance between the big and the small, between the glorious deed and the slight jest (as Plutarch would say), and to direct the reader's gaze toward the personal qualities of his subjects. Perhaps the best example of his technique is found in his Epaminondas. This Life, as Nepos promised, consists mainly of anecdotes that demonstrate the Theban general's honesty, intelligence and devotion to his fellow citizens. ${ }^{22}$ With one anecdote in particular Nepos joins the slight jest and the glorious deed to good effect ( $E p$. 10.1-2):

Hic uxorem numquam duxit. in quo cum reprehenderetur, quod liberos non relinqueret, a Pelopida, qui filium habebat infamem, maleque eum in eo patriae consulere diceret, "uide" inquit "ne tu peius consulas, qui talem ex te natum relicturus sis. neque uero stirps potest mihi deesse: namque ex me natam relinquo pugnam Leuctricam, quae non modo mihi superstes, sed etiam immortalis sit necesse est."

[Epaminondas] never married. Pelopidas, who had a notorious son, chastised him for this, because he was not leaving behind children, and said that he was thus not looking after the interests of his country well. "Be careful," Epaminondas replied, "that you are not looking after them even worse than

${ }^{21}$ In quo tanto plus uirtute ualuerunt Athenienses, ut decemplicem numerum hostium profligarint adeoque perterruerint, ut Persae non castra, se naues petierent. (1988).

${ }_{22}^{2}$ On Nepos' interest in the devotion to the public good as a virtue, see Dionisotti 
I am, since you will leave behind a son like yours. Nor can I actually ever lack offspring, for I leave behind the battle of Leuctra as my daughter, which is certain not only to survive me but even to be immortal."

This brief passage demonstrates a sophisticated biographical method and no small cleverness besides. Rather than a lengthy account of Leuctra, the universally acknowledged watershed battle in which the ascendant Thebes broke Sparta's military power, Nepos calls it to the reader's mind without allowing it to dominate the narrative, just as he did with Miltiades and the battle of Marathon. This leaves space to display two of Epaminondas' other significant achievements: most important, a lifelong devotion to his city, but also a quickness of wit that helped keep his political rivals at bay. Both qualities are thematic in the Life, and in this anecdote, they may be appreciated alongside Epaminondas' achievement on the battlefield and perhaps even be viewed as more important.

A closer look at the battle of Leuctra shows how tightly the big and the small are integrated in this text. In the opening of the Life, as we saw above, Nepos promised to cover a list of topics, with res gestae coming at the end. Epaminondas' greatest res, an "immortal" accomplishment as he himself reportedly called it, was the Theban victory at Leuctra. Nepos alludes to this battle at three points in the Life, each time as part of an anecdote that demonstrates an essential element of Epaminondas' character and that, significantly, takes the importance of Leuctra as read in order to be effective. ${ }^{23}$ Thus, even as Nepos stakes out a vita of Epaminondas that is distinct from history, he also relies upon his readers' knowledge of history to make his most important points. Nepos' public probably did include some who were truly expertes litterarum Graecarum, but there must have been others who could place these Lives in their larger historical context. $^{24}$

${ }^{23}$ In addition to the anecdote in Chapter 10, Nepos also uses Leuctra to demonstrate the power of Epaminondas' rhetorical skills and his political savvy. After describing several of his speeches, Nepos writes that the best demonstration of his eloquence occurred when he gave a speech to Sparta's assembled allies before the battle. There he "shattered [Spartan] power no less by that speech than by the battle of Leuctra, for at that moment he caused the Lacedaemonians to be deprived of the support of their allies, as later became apparent" (6.4). After the battle, when the Theban people were prosecuting him for holding the command at Leuctra illegally, he embarrassed them and won acquittal by wryly confessing that he had "compelled [the Thebans] to conquer the Lacedaemonians" and that he had thereby "won freedom for all of Greece" (8). A further example of the historical knowledge assumed by Nepos is Epaminondas' use of the phrase Messene restituta to refer obliquely to the liberation of the helots and the threat that posed to Sparta (8.5). Cf. Ag. 6.1, where Nepos refers to the battle simply as "the well-known disaster at Leuctra" (illa calamitas apud Leuctra). Apart from these allusions to the outcome of the battle, however, the significance of Leuctra in Greek history is not explained.

${ }^{24}$ Thus Horsfall (1989) $x i x-x x$ is again too harsh when he writes that Nepos had "to explain the historical background to the Foreign Generals to an audience who could 
But the reality of these ignorant readers is not of primary importance. Their value is in the use to which Nepos put them in establishing his biographical method in the Lives of the generals. Regardless of whether he was the first to write political biography, Nepos employed these "cross-grained readers" rhetorically in a conscious attempt to distinguish his vitae from historiae. In this he anticipates Plutarch, who wrote about the same generic distinction to help set his readers' expectations and to sift an abundance of historical material. ${ }^{25}$ Although their projects differ in many ways, both authors wrote about men whose accomplishments dominated the histories of their times, and they sought to direct the reader's attention to whatever matters, great or small, ordinary or foreign, would best reveal their virtue. ${ }^{26}$ Without making excuses for Nepos' inelegant style or the simplicity of his moralizing, we may still recognize that he understood the requirements of his genre and skillfully guided his reader toward the lessons he meant to convey. ${ }^{27}$

JEFFREY BENEKER

University of Wisconsin

\section{WORKS CITED}

Conte, Gian Biagio. 1994. Latin Literature: A History. Translated by J.B. Solodow. Revised by D. Fowler and G.W. Most. Baltimore and London.

Dionisotti, A.C. 1988. "Nepos and the Generals." JRS 78: 35-49.

Duff, Timothy E. 1999. Plutarch's Lives: Exploring Virtue and Vice. Oxford.

. 2008. "The Opening of Plutarch's Life of Themistokles." GRBS 48: 159-79. Geiger, Joseph. 1985. Cornelius Nepos and Ancient Political Biography. Stuttgart.

not read the Greek historians and therefore knew nothing of history beyond the Adriatic (Pelop. 1.1)." I venture to guess that several of Nepos' biographical subjects, like Iphicrates, Chabrias, Datames and even Eumenes, are obscure figures even for many modern Classicists.

${ }^{25}$ Plutarch, like Nepos, also assumed that his readers would bring a shared historical context to their reading of his Lives, though he assumed a more thorough knowledge and put it to greater use; see Pelling (2007); Duff (2008) 171.

${ }^{26}$ Suetonius was also aware of the need to distinguish biography from history, and his "reaction to the dilemma was vigorous" (Wallace-Hadrill (1983) 8-10). But unlike Nepos and Plutarch, he does not introduce into his text a genre-based argument for his method. Rather, his biographical method is reflected in the structure of his Lives and bluntly stated, without his predecessors' concern that his readers might quibble or be expecting more res gestae than he provides. Cf. Aug. 9.1: "Having presented essentially a summary of his life, I will now set forth the parts individually, not according to their chronology but by category, so that they may be explained and appreciated more clearly" (Proposita uitae eius uelut summa partes singillatim neque per tempora sed per species exsequar, quo distinctius demonstrari cognoscique possint).

${ }^{27}$ I would like to thank John Starks and Rex Stem for inviting me to join the Nepos panel at CAMWS 2008, where this paper originated. I am especially grateful to Rex and fellow panelist Molly Pryzwansky for their advice as I reworked the paper. I would also like to thank Craig Gibson, Carole Newlands, Christopher Pelling and S. Douglas Olson and the anonymous referees of The Classical Journal for valuable criticism that greatly improved the final version. 
Horsfall, Nicholas. 1982. "Prose and Mime." In Cambridge History of Classical Literature, vol. 2, part 2: The Late Republic, edited by E.J. Kenney, pp. 11220. Cambridge.

- 1989. Cornelius Nepos: A Selection, Including the Lives of Cato and Atticus. Oxford.

Jenkinson, Edna. 1967. "Nepos: An Introduction to Latin Biography." In Latin Biography, edited by T.A. Dorey, pp. 1-15. London.

— 1973. "Genus scripturae leve: Cornelius Nepos and the Early History of Biography at Rome." ANRW I.3: 703-19.

McCarty, Thomas G. 1974. "The Content of Cornelius Nepos' De viris illustribus." CW 67: 383-91.

Manuwald, Gesine. 2003. "'Der zweite Mann in Theben': Zur Pelopidas-Vita des Cornelius Nepos." Hermes 131: 441-55.

Marshall, Peter K., ed. 1991. Cornelii Nepotis Vitae cum Fragmentis. ${ }^{3}$ Stuttgart and Leipzig.

Millar, Fergus. 1988. "Cornelius Nepos, 'Atticus' and the Roman Revolution." GER 35: 40-55.

Moles, John L. 1989. Review of J. Geiger, Cornelius Nepos and Ancient Political Biography (1985), in CR NS 39: 229-33

— 1992. Review of N. Horsfall, Cornelius Nepos: A Selection, Including the Lives of Cato and Atticus (1989), in CR NS 42: 314-16.

Momigliano, Arnaldo. 1993. The Development of Greek Biography. Expanded edition. Cambridge, MA.

Pelling, Christopher. 2002a. "Plutarch's Caesar: A Caesar for the Caesars?" In Plutarch and History, edited by Christopher Pelling, pp. 253-65. London and Swansea.

_ 2002b. "'You for me and me for you...': Narrator and Narratee in Plutarch's Lives." In Plutarch and History, edited by Christopher Pelling, pp. 267-82. London and Swansea.

— 2006. "Breaking the Bounds: Writing about Caesar." In The Limits of Ancient Biography, edited by J.M. Mossman and B. McGing, pp. 255-80. London and Swansea.

—. 2007. "De Malignitate Herodoti? Plutarch, Herodotos and the Persian Wars." In Cultural Responses to the Persian Wars: Antiquity to the Third Millenium, edited by E.E. Bridges, E.M. Hall and P.J. Rhodes, pp. 145-64. Oxford.

Rawson, Elizabeth. 1985. Intellectual Life in the Late Roman Republic. Baltimore. Stadter, Philip A. 1988. “The Proems of Plutarch's Lives.” ICS 13: 275-95.

Tatum, W. Jeffrey. 1997. "Friendship, Politics, and Literature in Catullus: Poems 1, 65 and 66, 116." CQ NS 47: 482-500.

Titchener, Frances B. 2003. "Cornelius Nepos and the Biographical Tradition." GER 50: 85-99.

Tuplin, Christopher. 2000. "Nepos and the Origins of Political Biography." In Studies in Latin Literature and Roman History X, Collection Latomus, vol. 254, edited by C. Deroux, pp. 124-61. Brussels.

Wallace-Hadrill, Andrew. 1983. Suetonius: The Scholar and his Caesars. London.

Wiseman, T.P. 1979. Clio's Cosmetics: Three Studies in Greco-Roman Literature. Leicester. 